
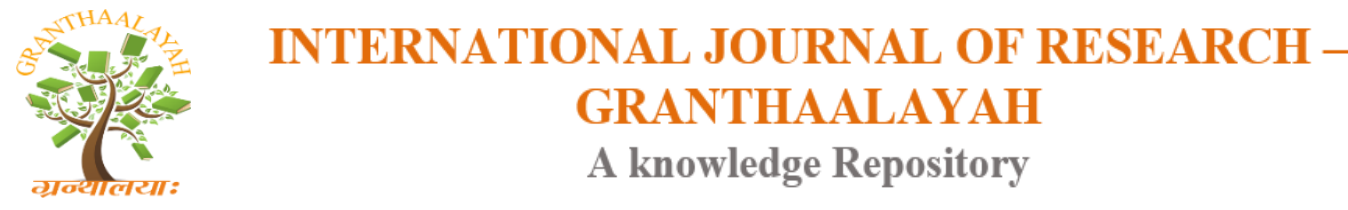

Management

\title{
ANALYSIS OF PRODUCTION AND INCOME OF CASSAVA FARMING
}

\author{
Laode Geo *1 \\ ${ }^{* 1}$ Agribusiness Department, Faculty of Agriculture, Halu Oleo University, 93232 Kendari, \\ Indonesia
}

\begin{abstract}
Motivation/Background: This study determining the amount of production and income of cassava farming, and level of efficiency of cassava farming in Muna Regency. The total sample was 32 farmers determined by stratified random sampling.

Method: The type of data used is primary data obtained through direct interviews with respondents of cassava farmers and secondary data from relevant agencies. Data were analyzed using income analysis and business efficiency.

Results: The results showed the average of amount of cassava farm production is $1.141 \mathrm{~kg}$ per farmer. The average income received by each farmers is Rp. 6,115,969.

Conclusions: The efficiency level of 6.10 which means that cassava farming is efficient and feasible to be developed.

Keywords: Production; Income; Business Efficiency; Cassava.

Cite This Article: Laode Geo. (2020). "ANALYSIS OF PRODUCTION AND INCOME OF CASSAVA FARMING.” International Journal of Research - Granthaalayah, 8(4), 160-166. https://doi.org/10.29121/granthaalayah.v8.i4.2020.21.
\end{abstract}

\section{Introduction}

Food crops are primer needs of people food and nutrition require. One strategy to overcome food insecurity is to increase food security. Food security policy is an important agenda in economic development. The change of paradigm in economic development policy that initially started from the growth-oriented development paradigm, then development oriented towards equity, and finally the sustainable development paradigm that is more concerned with the preservation of natural resources that can overcome the problem of food insecurity. For example, rice is very risky to food security issue, so it needs efforts to develop alternative food crops such as corn, soybeans, green beans, cassava, taro, and gembili which all can be processed into various foods that have more econimic value ${ }^{[1]}$.

Province of Southeast Sulawesi is one of the 10 highest cassava development centers in Indonesia. Cassava is one of the tuber-type food plants that has the potential to be developed in Muna Regency. Processed food sourced from cassava plants is one of the staple foods which is processed 
in various forms and consumed for generations by the local community. Cassava food plants which are optimally cultivated are expected to be one of the sources of increased production to fill the food needs of the community as well as a source of income for farmers. The data on the development of harvested area, production and productivity of cassava farming in Muna Regency and other Regencies/Cities in Southeast Sulawesi Province can be seen in Table 1.

Table 1: Harvest Area, Production and Productivity of Cassava Farming in Muna Regency in $2018^{[2]}$.

\begin{tabular}{|l|c|c|c|}
\hline \multirow{2}{*}{ Regency } & \multicolumn{3}{|c|}{ Cassava } \\
\cline { 2 - 4 } & Harvest Area & Production & Productivity \\
\hline Buton & 593.0 & $16,435.7$ & 27.7 \\
\hline Muna & $1,173.0$ & $27,563.8$ & 23.5 \\
\hline Konawe & 246.3 & $6,184.4$ & 25.1 \\
\hline Kolaka & 112.1 & $3,629.6$ & 32.4 \\
\hline South Konawe & $1,315.4$ & $22,300.6$ & 17.0 \\
\hline Bombana & 70,9 & $1,546.7$ & 21.8 \\
\hline Wakatobi & $2,498.9$ & $50,978.3$ & 20.4 \\
\hline North Kolaka & 36.0 & 703.9 & 19.6 \\
\hline North Buton & 150.0 & $5,654.8$ & 37.7 \\
\hline North Konawe & 129.0 & $3,191.7$ & 24.7 \\
\hline East Kolaka & 254.0 & $6,801.0$ & 26.8 \\
\hline Konawe Island & 135.2 & $3,230.1$ & 23.9 \\
\hline West Muna & 252.0 & $8,075.6$ & 32.0 \\
\hline Centre Buton & 519.0 & $22,195.4$ & 42.8 \\
\hline South Buton & $1,036.0$ & $27,097.8$ & 26.2 \\
\hline Kendari & 178.0 & $2,969.6$ & 16.7 \\
\hline Bau-Bau & 83.0 & $1,827.6$ & 22.0 \\
\hline Southeast Sulawesi & $\mathbf{8 , 7 8 1 . 8}$ & $\mathbf{2 1 0 , 3 8 6 . 6}$ & $\mathbf{2 4 . 0}$ \\
\hline
\end{tabular}

Source: The Central of Burbau Statistics 2019

Muna Regency is one of the regencies that has potential harvested area, production and productivity to be developed. Sustainability of food security policies with the availability of food through cassava farming is determined by the level of welfare of farmers which was measured by the income received. This should be the subject of government policy, due to farmers are the spearhead in providing food supplies as revealed by the Minister of National Development Planning/Head of Bappenas ${ }^{[3]}$.

\section{Materials and Methods}

This research was conducted in Muna Regency, at the districts of Tongkuno and Kabawo. The location was chosen purposively with consideration of potential research locations in the development of cassava farming. The population of the study was 128 farmers, and because of the population was more than 100 so the sample was taken as much as 25 percent of the population that are 32 farmers ${ }^{[4]}$. 
The sampling method uses stratified random sampling. The type of data is primary data obtained through direct interviews using a list of questions to cassava farmers in the form of data on land area, production, price, planting period, use of farming inputs, income, and production costs. Whereas secondary data was obtained through document searches from the relevant agencies. The method used in this research is quantitative descriptive. Data analysis to determine the income and efficiency of cassava farming is analyzed using income and business efficiency analysis. Income analysis using the following formulation according to Hernanto: $\mathrm{I}=\mathrm{TR}-\mathrm{TC}$, where: I: Income, TR: Total Revenue, and TC: Total Cost, while business efficiency uses ratio revenue cost (R-C ratio) ${ }^{[5]}$.

\section{Result and Discussion}

\subsection{Overview of Research Locations}

Muna Regency is one of the centers of food crops in Southeast Sulawesi Province. Cassava farming has long been endeavored by the local community to fulfill and supply their basic needs. with soil conditions, temperature and rainfall in Muna Regency, cassava plants are quite adaptive and can grow well. Data related to the area of cassava harvest is presented in Table 2.

Table 2: Land area, heigh of region and cassava harvest area

\begin{tabular}{|l|c|c|c|c|c|}
\hline District & Land Area $\left.\mathbf{( k m}^{\mathbf{2}}\right)$ & Percent & Heigh of Region (dpl) & Harvest Area & Percent \\
\hline Tongkuno & 440,98 & 21,43 & 62 & 187 & 21,72 \\
\hline Kabawo & 209,94 & 10,2 & 50 & 136 & 15,80 \\
\hline Muna & 2057,69 & 100 & & 861 & 100 \\
\hline
\end{tabular}

Source: The Central of Burbau Statistics 2019

Tongkuno District has an region area of $440.98 \mathrm{~km}^{2}$ or 21.43 percent of the area of Muna Regency, while Kabawo District has an region area of $209.94 \mathrm{~km}^{2}$ or 10.20 percent of the area of Muna Regency. The harvest area used for cassava farming in Tongkuno District is $187 \mathrm{~km}^{2}$, while Kabawo Regency is $136 \mathrm{~km}^{2}$.

Table 3: Identity of Respondents by Age

\begin{tabular}{|l|c|c|}
\hline Age & Total & Percentage \\
\hline (year) & (Person) & $\mathbf{( \% )}$ \\
\hline $31-40$ & 3 & 9 \\
\hline $41-50$ & 12 & 38 \\
\hline $51-60$ & 13 & 41 \\
\hline $61-70$ & 4 & 13 \\
\hline Total & $\mathbf{3 2}$ & $\mathbf{1 0 0}$ \\
\hline
\end{tabular}

Cassava Farmers in this study who had an average age of 31-40 years are three people, an average age of 41-50 years are 12 people and an average age of 51-60 years are 13 people and an average age of 61-70 are four people. In general, the age of farmers is still in their productive age in farming. With a productive age, physical constraints experienced will be minimal, so that it will affect the sustainability of cassava farming production. 
Table 4: Identity of Respondents Based on Farming Experience

\begin{tabular}{|c|c|c|}
\hline Farming Experience (year) & Total (Person) & Percentage (\%) \\
\hline$<10$ & 8 & 25 \\
\hline $10-20$ & 19 & 59 \\
\hline$>\mathbf{2 0}$ & $\mathbf{5}$ & $\mathbf{1 6}$ \\
\hline Total & $\mathbf{3 2}$ & $\mathbf{1 0 0}$ \\
\hline
\end{tabular}

In running a farm, the experience factor is also very influential in achieving optimal production results. It is due to with the experience they have, the activities of cassava farming will be more effective. In this study, cassava farmers still use traditional methods that are traditionally done from generation to generation. Farming which is usually done in traditional ways has now begun to be socialized by related agencies to be abandoned, and changed to more modern farming patterns, and the application of technology which make increase in productivity. The results showed that most farmers have experienced cassava farming. They had been farming for more than 10 years and included in the medium category.

Table 5: Identity of Respondents by Land Area

\begin{tabular}{|l|c|c|}
\hline Land Area (Ha) & Total & Percentage (\%) \\
\hline $0.5-1.00$ & 14 & 44 \\
\hline $1.01-2.00$ & 18 & 56 \\
\hline Total & $\mathbf{3 2}$ & $\mathbf{1 0 0}$ \\
\hline
\end{tabular}

Cassava farming carried out by respondents are known to have an area of 0.5-1.00 Ha were 14 people, and an area of 1.01-2.00 Ha were 18 people. Most farmers use their own land, so there is no need to pay for land rent.

\subsection{Production Analysis}

Production is a result of activities combining various factors of production in the form of capital, while labors, technology and managerial ability to produce benefits ${ }^{[6]}$. Data about cassava farming production information is very important as a basis in formulating policies. By knowing production data every season/year, there will be a trend of development or decline in the results of farming. The following presents data on the development of harvested area, production and productivity of cassava farming in Muna Regency in the last 3 years.

Table 6: Data of land area development, production and productivity cassava farming in Muda District in 2016-2018

\begin{tabular}{|l|c|c|c|c|c|}
\hline \multirow{2}{*}{ Information } & \multicolumn{3}{|c|}{ Years } & Avergae & Growth \\
\cline { 2 - 4 } & $\mathbf{2 0 1 6}$ & $\mathbf{2 0 1 7}$ & $\mathbf{2 0 1 8}$ & & \\
\hline Harvest Area (Ha) & 861 & 978 & 1132 & 990,33 & 31,48 \\
\hline Production (Ton) & 25533 & 28678 & 28866 & 27.692 & 13,05 \\
\hline Productivity (Ton/Ha) & 29,66 & 29,32 & 25,50 & 28,16 & $(14,01)$ \\
\hline
\end{tabular}

Based on the data in Table 6, it can be seen that the harvested area and production have always increase over the last three years with an average harvested area was $990 \mathrm{Ha}$, an average production 
27.692 tons, and average productivity was 28.16 tons/ha . Average harvested area growth was 31.48 percent, production growth 13.05 percent and productivity decreased by 14.01 percent over the past three years. With these facts, of course this has become a field phenomenon, when the socialization of food security is incessant, but the productivity of cassava farming actually decreases. Cassava farming is only one harvest per year. So the calculation of the analysis is calculated per year.

Table 7: Respondents based on average of casava farming production

\begin{tabular}{|l|c|c|}
\hline \multirow{2}{*}{ District } & Number or Farmers & Production \\
\cline { 2 - 3 } & (people) & $\mathbf{( K g )}$ \\
\hline Tongkuno & 18 & 24.353 \\
\hline Kabawo & 14 & 14.657 \\
\hline Total & $\mathbf{3 2}$ & $\mathbf{3 9 . 0 1 0}$ \\
\hline Average & & $\mathbf{1 . 2 1 9}$ \\
\hline
\end{tabular}

The total production of cassava farming was 32 farmers, which was $39.010 \mathrm{~kg}$ per harvest season, with details of $24.353 \mathrm{~kg}$ in Tongkuno District and $14.657 \mathrm{~kg}$ in Kabawo District. Average production per respondent was $1.219 \mathrm{~kg}$ per planting season.

\subsection{Analysis of Cassava Farming Income}

To find out the income of cassava farming, revenue and production costs was analyzed first and that can be seen in detail in the following table:

Table 8: Data of revenue and producon cost cassava farming

\begin{tabular}{|l|c|c|c|c|}
\hline \multirow{2}{*}{ Respondents } & Production & Price & Revenue & Cost \\
\cline { 2 - 5 } & $(\mathbf{K g})$ & $(\mathbf{R p})$ & $(\mathbf{R p})$ & $(\mathbf{R p )}$ \\
\hline 1 & 1.380 & 6000 & $8,280,000$ & 885,000 \\
\hline 2 & 2.551 & 6000 & $15,305,000$ & $5,183,000$ \\
\hline 3 & 793 & 6000 & $4,760,000$ & 766,000 \\
\hline 4 & 896 & 6000 & $5,375,000$ & 828,000 \\
\hline 5 & 1.043 & 6000 & $6,260,000$ & 728,000 \\
\hline 6 & 868 & 6000 & $5,210,000$ & 865,000 \\
\hline 7 & 1.291 & 6000 & $7,748,000$ & $1,001,666$ \\
\hline 8 & 2.707 & 6000 & $16,242,500$ & $2,920,500$ \\
\hline 9 & 810 & 6000 & $4,860,000$ & 885,000 \\
\hline 10 & 1.961 & 6000 & $11,764,000$ & $1,828,666$ \\
\hline 11 & 770 & 6000 & $4,620,000$ & 820,000 \\
\hline 12 & 903 & 6000 & $5,420,000$ & 978,000 \\
\hline 13 & 1.163 & 6000 & $6,975,000$ & $1,087,500$ \\
\hline 14 & 1.670 & 6000 & $10,020,000$ & $1,745,000$ \\
\hline 15 & 1.253 & 6000 & $7,520,000$ & 887,000 \\
\hline 16 & 1.276 & 6000 & $7,655,000$ & $1,025,000$ \\
\hline 17 & 2.221 & 6000 & $13,325,000$ & $1,410,000$ \\
\hline
\end{tabular}




\begin{tabular}{|l|c|c|c|c|}
\hline 18 & 797 & 6000 & $4,780,000$ & 745,000 \\
\hline 19 & 877 & 6000 & $5,260,000$ & 668,000 \\
\hline 20 & 1.156 & 6000 & $6,935,000$ & $1,085,000$ \\
\hline 21 & 1.126 & 6000 & $6,755,000$ & $1,380,000$ \\
\hline 22 & 1.308 & 6000 & $7,850,000$ & 989,500 \\
\hline 23 & 1.665 & 6000 & $9,987,000$ & $1,545,666$ \\
\hline 24 & 692 & 6000 & $4,152,000$ & 620,000 \\
\hline 25 & 763 & 6000 & $4,575,000$ & $1,014,000$ \\
\hline 26 & 684 & 6000 & $4,105,000$ & 696,000 \\
\hline 27 & 692 & 6000 & $4,150,000$ & 618,000 \\
\hline 28 & 1.612 & 6000 & $9,670,000$ & 675,000 \\
\hline 29 & 1.094 & 6000 & $6,565,000$ & $1,289,000$ \\
\hline 30 & 692 & 6000 & $4,150,000$ & 625,000 \\
\hline 31 & 893 & 6000 & $5,360,000$ & 982,000 \\
\hline 32 & 1.405 & 6000 & $8,428,000$ & $1,575,000$ \\
\hline Total & 39.010 & & $234,061,500$ & $38,350,498$ \\
\hline Average & 1.219 & & $7,314,422$ & $1,198,453$ \\
\hline
\end{tabular}

The total revenue received by all respondents in the cassava farming every year was Rp. 234,061,500 per harvest season. The average revenue received by each respondent every year was Rp. 7,314,422 per harvest season. The total cost that must be spent by respondents in the cultivation of cassava each year was Rp. 38,350,498 per harvest season, while the average cost incurred by each respondent each year was Rp. 1,198,453 per harvest season. Based on field facts, all cassava yields are sold in the form of commodities without any processing in the form of products ready for consumption so that the income are received very little. The local people in the study area has not been able to process cassava in the form of processed which has added value so that it can contribute to increasing income.

\subsection{Analysis of Revenue and Business Efficiency}

Table 9: Analysis result of revenue and business efficiency cassava farming

\begin{tabular}{|l|c|c|c|c|}
\hline \multirow{2}{*}{} & Revenue & Cost & Income & \multirow{2}{*}{ R-C Ratio } \\
\cline { 2 - 5 } & $(\mathbf{R p})$ & $(\mathbf{R p})$ & $(\mathbf{R p )}$ & \\
\hline Total & $234,061,500$ & $38,350,498$ & $195,711,002$ & 6.10 \\
\hline Average & $7,314,422$ & $1,198,453$ & $6,115,969$ & 6.10 \\
\hline
\end{tabular}

The income received by all respondents in each year was Rp. 195,711,002, while the average income received by each respondent farmer in each planting season was Rp. 6,115,969, while the results of the analysis of business efficiency using the R-C ratio was obtained results of 6.10, this implies that cassava farming is quite efficient and profitable to continue to be endeavored.

\section{Conclusion}

The production average of cassava farming was $1.141 \mathrm{~kg}$. The total income received by farmers amounted to Rp. 195,711,002, and the average of income was received by each farmer was Rp. 
$6,115,969$, while the level of business efficiency was 6.10 , which means that cassava farming is efficient and feasible to be developed.

\section{Acknowledgements}

Author would acknowledge to Muna Regency Government and all cassava farmers who has helped this research.

\section{References}

[1] Geo, L. and Muthalib AA. Kajian Ekonomi Tentang Produk Unggulan Strategis Non Beras dalam Percepatan dan Perluasan Pembangunan Tanaman Pangan Di Provinsi Sulawesi Tenggara. Hasil Penelitian MP3EI. 2015, Universitas Halu Oleo. Kendari.

[2] The Central of Burbau Statistics. Southeast Sulawesi on Number. Kendari. Sulawesi Tenggara; 2019.

[3] Geo, L. 2015. Keragaman Peoduk Tanaman Pangan Antar Wilayah Di Peovinsi Sulawesi Tenggara. Kendari. 2015.

[4] Arikunto S. Prosedur Penelitian suatu Pendekatan Praktik. Rineka Cipta. Jakarta; 2006.

[5] Hernanto F. Ilmu Usahatani. Penebar Swadaya. Jakarta; 2006.

[6] Welang, FR., Joachim, NKD. and Martha, MS. Analisis usahatani padi sawah berdasarkan musim panen di Kelurahan Taratara Satu Kecamatan Tomohan Barat Kota Tomohon. Agri-socio Ekonomi, 2016, 107-124.

*Corresponding author.

E-mail address: geolaode@yahoo.co.id 